\title{
Restoration of Obliterated Stamped Marks on Aluminium Surfaces by Metallographic Etching Technique
}

\author{
AMIT KUMAR ${ }^{1}$, ANKIT SRIVASTAVA ${ }^{2}$, TANURUP DAS ${ }^{3}$, ABHIMANYU HARSHEY ${ }^{4}$, VEER \\ RAJ SAINI ${ }^{5}$, AKASH KUMAR ${ }^{6}$, MD. ALIM ${ }^{7}$, KRITI NIGAM ${ }^{8}$ and VIJAY KUMAR YADAV ${ }^{9 *}$ \\ 1, 2,3,4,6,7,8,9,Dr. A.P.J. Abdul Kalam Institute of Forensic Science \& Criminology, Bundelkhand University, \\ Jhansi 284128, Uttar Pradesh. \\ ${ }^{5}$ Regional Forensic Science Laboratory, Muradabad, Uttar Pradesh, India. \\ ${ }^{*}$ Corresponding author E-mail: vijayforensic01@gmail.com
}

http://dx.doi.org/10.13005/ojc/360628

(Received: November 11, 2020; Accepted: December 13, 2020)

\section{ABSTRACT}

\begin{abstract}
Serial number restoration is a frequently encountered problem in forensic science laboratories for the investigation of theft and burglary cases. These identification marks are generally introduced over metallic surfaces of different vehicle parts and firearms by various means. Chemical etching is one of the most effective and simple technique to restore obliterated, erased, over-stamped and over-engraved marks on metallic surfaces. Several significant studies on restoration of engraved markings on aluminium surfaces were previously reported. The present study attempts to find out an efficient and fast etching reagent to restore obliterated stamped marks on aluminium surfaces. Ten effective etching reagents previously reported by various researchers in their restoration studies were assessed in the present experiment. Etching reagents were individually applied on obliterated surfaces by the cotton swabbing method. The Reagent 3 (ferric chloride $25 \mathrm{~g}$, conc. $\mathrm{HCl} 25 \mathrm{~mL}$, distilled water $100 \mathrm{~mL}$ ) was found out to be the most sensitive and rapid (4-6 min) for the restoration on aluminium surfaces. The study also revealed that the absence of an alkaline compound in etching reagent potentially accelerates the speed of the restoration process.
\end{abstract}

Keywords: Serial number, Aluminium, Stamped marks, Obliteration, Etching reagent, Restoration.

\section{INTRODUCTION}

Serial numbers are unique identification marks placed on engines and chassis of vehicles, firearm frames or any other metallic object ${ }^{1-4}$. Casting, Engraving, die stamping, pin stamping and LASER are commonly used to introduce these identification marks on the metallic surfaces ${ }^{5,6}$. On the contrary, perpetrators frequently obliterate or remove these marks by several mechanical means i.e., peening, punching, filing, grinding, drilling, welding over-stamping, chemical corrosion, etc. for unauthorized selling and to avoid any connection with the item1, 2, 6 - 8. Restoration of the obliterated or removed identification marks provides major leads in the identification of stolen objects ${ }^{2,9}$. The marking process deforms several layers underneath the actual indentation. The depth of deformation

This is an Open Access article licensed under a Creative Commons license: Attribution 4.0 International (CC- BY). Published by Oriental Scientific Publishing Company @ 2018 
depends on the strength of the metal, e.g., on impact, zinc deforms more than iron ${ }^{10}$ (Fig. 1a-1c). The efficiency of restoration depends upon the depth of obliteration. Treatment of the surface with different chemicals known as macro etching is the most common restoration technique used by the researchers on metals. Macro etching is the most effective metallographic technique among all ${ }^{11}$.

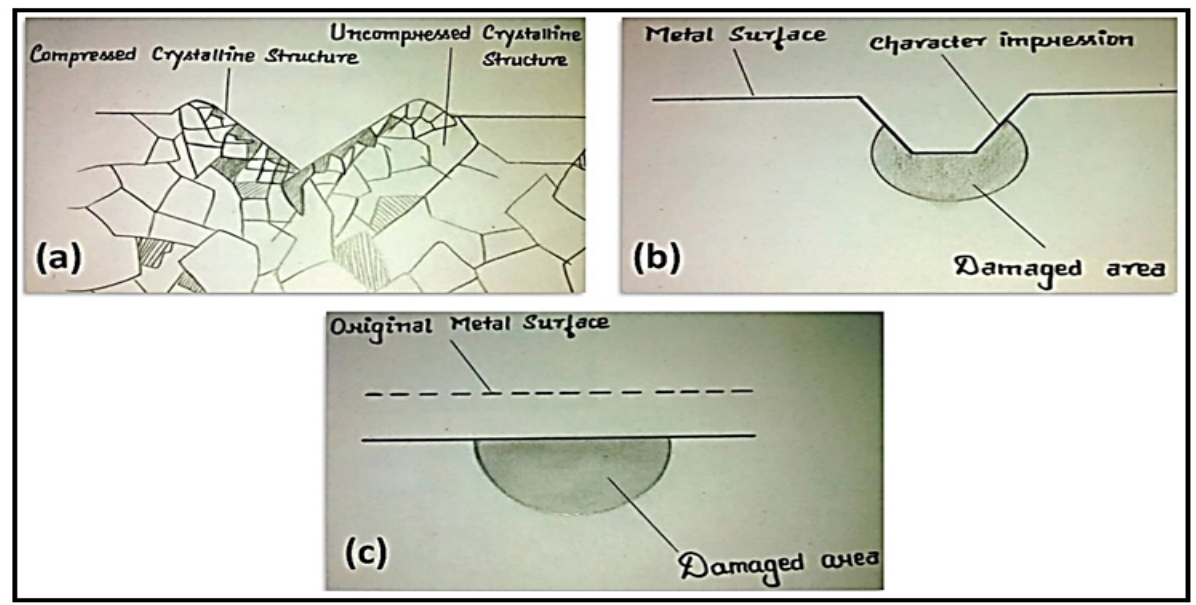

Fig. 1. Cross-section of deformed crystal structure by mechanical force

A desirable etching reagent for metallic surface always give good contrast, reproducibility and consume less time for restoration. A large number of significant studies have been performed on commonly encountered metals and their alloys. Works by Turley ${ }^{12}$, Zaili et al., ${ }^{7}$, Wightman and Matthew ${ }^{1}$, Yin and Kuppuswamy ${ }^{13}$, Wahab et al., ${ }^{11}$ and Richa et al., ${ }^{4}$, showed that different composition of 'Fry's Reagent' consists of a metallic halide or salts and a strong acid is an excellent etching reagent for iron and steel surfaces. Recently Shankar et al., ${ }^{3}$ restored obliterated serial markings on copper by a combination of ferric chloride, glacial acetic acid and distilled water and Fortini et al., ${ }^{14}$ restored obliterated markings on $\mathrm{Ni}-\mathrm{Cr}-\mathrm{Mo}$ steel surface by a combination of Nitric acid and distilled water.

Aluminium and its alloys are rapidly replacing other metals in the vehicle, firearm and machinery industry in recent decades due to its strength and lightweight ${ }^{2,15-16}$. Different alloys (e.g. Duralumin) of aluminium also used frequently in various automobile industries ${ }^{16}$. Restoration on aluminium surfaces were previously performed only on obliterated engraved marks $^{2,9,10,15,17}$. Studies by Chisum ${ }^{15}$, Baharum et al., ${ }^{10}$, Peeler et al., ${ }^{17}$ Bong and Kuppuswamy ${ }^{9}$ and Uli et al., ${ }^{2}$ revealed that etching reagents used for comparatively strong metals and their alloys like iron, steel, etc. are not suitable for the restoration of obliterated engraved marks on aluminium and its alloy surfaces. Few researchers recommended that an alternate application of a dilute solution of a strong acid and a strong alkali can be a good etching reagent on aluminium surfaces ${ }^{2,9,10}$. Present study assessed ten best etching reagents used in previous studies of restoration on different metallic surfaces to find out a fast and effective reagent for the restoration of obliterated stamped marks on aluminium surface.

\section{Methodology}

In the present study $12.1 \mathrm{~mm}$ thick aluminium bricks were used to restore obliterated serial numbers created by punching method. Metallographic etching or chemical etching techniques is used for the restoration in the present study. The procedure of this method has been adapted from the previous studies of restoration of obliterated engraved marks on aluminium and it alloy surfaces $2,9,10,15,17$.

\section{Sample Preparation}

A stamping die was used to introduce numeric characters from 1 to 9 . Each character of the die stamp covers approximately 0.3 square inch area. Finally, all the samples were obliterated by the mechanical grinding machine (Fig. 2) up to zero visibility. Samples were photographed before and after each step for permanent record and comparison.
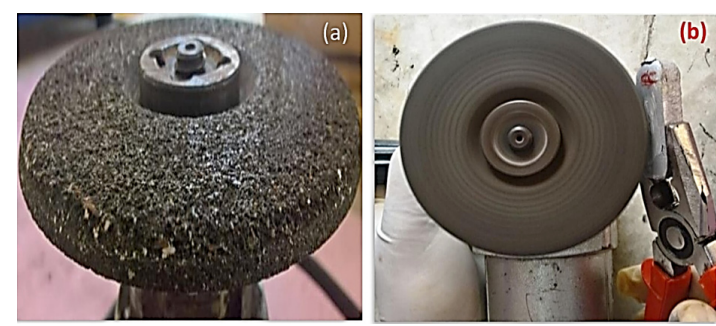

Fig. 2. Damaged area underneath the deformed crystal Layer 
Preliminary Examination and Surface Preparation

Surface preparation before restoration is the compulsory step as it makes the surface uniform which in turn enhance the efficiency of the restoration. All the samples were first examined by a magnifying lens to observe any remaining visible number. Commercially available silicon carbide paper (P 60) is used to polish the grinded surface by removing scratches and other marks to give a smooth mirrorlike finish for better chemical treatment. Polishing is followed by swabbing the surface with acetone to remove any dirt, grease, paint or any other loosely adherent material from the surface.

\section{Chemical Etching}

In the present work ten etching reagents
Table 1 were selected from previous studies of restoration on metallic surfaces. All the selected reagents are best in their respective studies. Reagent 1,2 and 6 were previously used on the aluminium and its alloy surfaces (Al-Zn-Mg-Cu and Al-Si). Reagents were applied on the obliterated surface by swabbing method. A cotton bud is soaked in the reagent and gently applied over the obliterated aluminium surfaces until the marks restored. Single reagents were swabbed uninterruptedly and multi-reagents were applied alternatively until the numbers restore. Since, the restored numbers were visible for a short period of time, instant photographs were captured to keep a permanent record before and after every step. The application method and composition of each reagent are summarized in the Table 1.

Table 1: Comparative effectiveness and sources of chemical etching reagents for the restoration of obliterated stamped marks on aluminium surfaces

\begin{tabular}{|c|c|c|c|c|c|c|}
\hline S. No. & $\begin{array}{l}\text { Etching } \\
\text { Reagent }\end{array}$ & Composition of Reagent & Application Method & $\begin{array}{l}\text { Consumed } \\
\text { Time }\end{array}$ & Observation & Source \\
\hline 1 & $\begin{array}{l}\text { Reagent } 1 \\
\text { (Villella's } \\
\text { reagent) }\end{array}$ & $\begin{array}{l}\text { Glycerine } 30 \mathrm{~mL} \\
\text { Hydrofluoric acid } 20 \mathrm{~mL} \\
\text { Nitric acid } 10 \mathrm{~mL}\end{array}$ & $\begin{array}{l}\text { Continuously swabs } \\
\text { the reagent until the } \\
\text { numbers appear. }\end{array}$ & $20-25$ & $\begin{array}{l}\text { Both contrast and } \\
\text { reproducibility were } \\
\text { good and can be } \\
\text { easily photographed. }\end{array}$ & Heard, $2008^{6}$ \\
\hline 2 & $\begin{array}{l}\text { Reagent } 2 \\
\text { (Hume Rothery } \\
\text { solution) }\end{array}$ & $\begin{array}{l}\text { Copper Chloride }\left(\mathrm{CuCl}_{2}\right) 200 \mathrm{~g} \\
\text { Hydrochloric Acid }(\mathrm{HCl}) 5 \mathrm{ml} \\
\text { Distilled water } 1000 \mathrm{~mL}\end{array}$ & $\begin{array}{l}\text { The solution was } \\
\text { swabbed alternatively } \\
\text { on the erased surface. } \\
\text { First with Hume Rothery } \\
\text { solution and then with } \\
\text { distilled water. }\end{array}$ & 20 & $\begin{array}{l}\text { The number appears } \\
\text { in good contrast and } \\
\text { also reproducible. }\end{array}$ & $\begin{array}{l}\text { Baharum et al., }{ }^{6,11} \\
2008, \text { Heard, } 2008\end{array}$ \\
\hline 3 & Reagent 3 & $\begin{array}{l}\text { Ferric Chloride }\left(\mathrm{FeCl}_{3}\right) 25 \mathrm{~g} \\
\mathrm{HCl} 25 \mathrm{~mL} \\
\text { Distilled water } 100 \mathrm{~mL}\end{array}$ & $\begin{array}{l}\text { The reagent was } \\
\text { swabbed continuously } \\
\text { until the numbers appear. }\end{array}$ & r. & $\begin{array}{l}\text { Good contrast, easily } \\
\text { observed and reproducible. } \\
\text { Can be easily photographed. }\end{array}$ & Richa et al., 2012 \\
\hline 4 & Reagent 4 & $\begin{array}{l}\text { Solution } 1 \\
\text { Copper Chloride } 45 \mathrm{~g} \\
\mathrm{HCl} 100 \mathrm{~mL} \\
\text { Distilled water } 180 \mathrm{~mL} \\
\text { Solution } 2 \\
15 \% \text { Nitric acid }\end{array}$ & $\begin{array}{l}\text { Both solutions were } \\
\text { swabbed alternatively } \\
\text { on the erased surface. } \\
\text { until the numbers appear. }\end{array}$ & r. & No restoration. & Wahab et. al., $2012^{11}$ \\
\hline 5 & Reagent 5 & $\begin{array}{l}\text { Conc. } \mathrm{HCl} 10 \mathrm{~mL} \\
\text { Glacial acetic acid } 25 \mathrm{~mL}\end{array}$ & $\begin{array}{l}\text { The solution was applied } \\
\text { continuously until the } \\
\text { numbers appear. }\end{array}$ & 30 & $\begin{array}{l}\text { Numbers appeared in fair } \\
\text { contrast and slightly } \\
\text { observable and also } \\
\text { reproducible. }\end{array}$ & Shankar et al., $2014^{3}$ \\
\hline 6 & Reagent 6 & $\begin{array}{l}\text { Solution } 1 \\
10 \% \text { Sodium hydroxide } \\
\text { Solution } 2 \\
10 \% \text { Nitric acid }\end{array}$ & $\begin{array}{l}\text { Both the solution was } \\
\text { swabbed alternatively } \\
\text { on the erased surface. } \\
\text { First with solution } 1 \text { for } 3 \\
\text { minutes. Then solution } 2 \\
\text { for } 1 \text { minute. }\end{array}$ & 60 & $\begin{array}{l}\text { Both contrast and } \\
\text { reproducibility were } \\
\text { good and the sensitivity } \\
\text { of numbers was also good. }\end{array}$ & $\begin{array}{l}\text { Uli et al. } 2010^{2} \text {, } \\
\text { Petterd, } 2000 \\
\text { Bong and } \\
\text { Kuppuswamy, } 2010^{9}\end{array}$ \\
\hline 7 & Reagent 7 & $\begin{array}{l}\text { Solution } 1 \\
10 \% \text { Sodium hydroxide }(\mathrm{NaOH}) \\
\text { Solution } 2 \\
25 \% \text { Nitric acid }\left(\mathrm{HNO}_{3}\right) \\
\text { (Used as highlighter } \\
\text { for the above chemical) }\end{array}$ & $\begin{array}{l}\text { Swabs with } \mathrm{NaOH} \\
\text { and then } \mathrm{HNO}_{3}\end{array}$ & 58 & & $\begin{array}{l}\text { Technical Procedure } \\
\text { of reagent preparation } \\
2014^{19}\end{array}$ \\
\hline 8 & Reagent 8 & $\begin{array}{l}10 \% \text { Sodium hydroxide } \\
\text { Distilled water } 90 \mathrm{~mL}\end{array}$ & $\begin{array}{l}\text { Continuusly swabbing over } \\
\text { the erased surface until } \\
\text { the numbers appear. }\end{array}$ & er 50 & $\begin{array}{l}\text { Numbers are reproducible } \\
\text { and appeared in good contrast. }\end{array}$ & Katterwe, $2006^{20}$ \\
\hline 9 & Reagent 9 & $\begin{array}{l}\text { Nitric acid } 25 \mathrm{~mL} \\
\text { Distilled water } 75 \mathrm{~mL}\end{array}$ & & 90 & No restoration. & Petterd, $2000^{18}$ \\
\hline 10 & Reagent 10 & $\begin{array}{l}\text { Nitric acid } 20 \mathrm{~mL} \\
\text { Potassium } \\
\text { permanganet } 4 \mathrm{~g} \\
\text { Distilled water } 100 \mathrm{~mL}\end{array}$ & & 90 & & Shankar et al., $2014^{3}$ \\
\hline
\end{tabular}




\section{RESULTS}

The present study is focused to find out an effective and rapid chemical reagent to restore obliterated stamped serial numbers on aluminium surfaces. Several researchers explored multiple reagents to restore obliterated serial numbers on different metallic surfaces. ${ }^{10}$ best etching reagents from different restoration studies on aluminium and other metallic surfaces were selected for the present experiment. The experimental result shows that 7 among 10 reagents (i.e., Reagent 1: Glycerine $30 \mathrm{ml}$, Hydrofluoric acid $20 \mathrm{~mL}$, Nitric acid $\left(\mathrm{HNO}_{3}\right) 10 \mathrm{~mL}$, Reagent 2: Copper Chloride $200 \mathrm{~g}$, Hydrochloric Acid $50 \mathrm{~mL}$, Distilled water $1000 \mathrm{~mL}$, Reagent 3: Ferric Chloride $25 \mathrm{~g}$, Hydrochloric Acid $25 \mathrm{~mL}$, Distilled water $100 \mathrm{~mL}$, Reagent 5: Conc. Hydrochloric Acid $10 \mathrm{~mL}$, Glacial acetic acid $25 \mathrm{~mL}$, Reagent 6: 10\% Sodium hydroxide $(\mathrm{NaOH}), 10 \% \mathrm{HNO}_{3}$, Reagent 7: $10 \% \mathrm{NaOH}, 25 \% \mathrm{HNO}_{3}$ and Reagent 8: $10 \%$ $\mathrm{NaOH}$, Distilled water $90 \mathrm{~mL}$ ) successfully restored the obliterated marks. But, only three reagents i.e., Reagent 1 (Villella's reagent), Reagent 2 (Hume Rothary Solution) and Reagent 3 (Ferric Chloride $25 \mathrm{~g}$, Hydrochloric Acid $25 \mathrm{~mL}$, Distilled water 100 $\mathrm{mL}$ ) showed good restoration efficiency in less time (4-25 min) Fig. 3.a-3c, 4a-4.c). Reagent 3 was the standout among all as it took the least time (4-6 $\mathrm{min}$ ) and also produce good visibility (Fig. 5.a-5c) of restored numbers. This experiment also revealed that reagents containing alkali, took comparatively less time (4-30 $\mathrm{min}$ ) to restore the obliterated marks than the reagents containing it (50-60 $\mathrm{min}$ ). Table 2 shows the comparative representation of the consumed time by reagents including alkali and without alkali. Reagent 4, 9 and 10 showed no restoration on the aluminium surface.

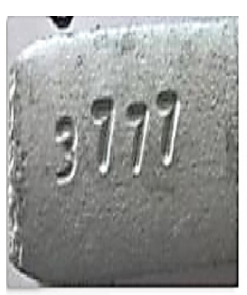

(a)

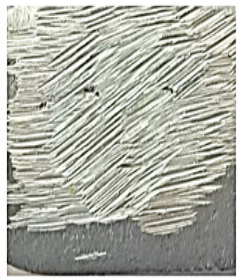

(b)

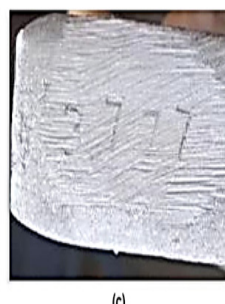

(c)

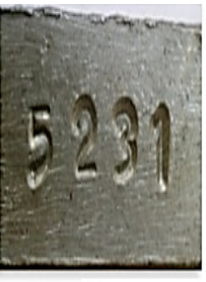

(a)

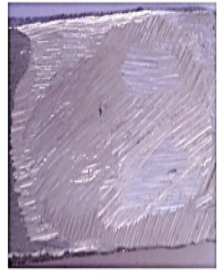

(b)

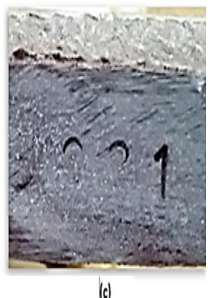

Fig. 4. Serial mark (a) pre obliteration (b) post obliteration (c) restored by Hume Rothary solution

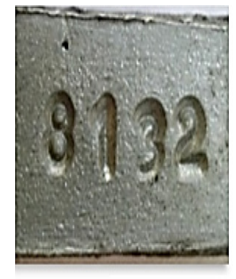

(a)

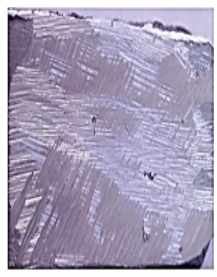

(b)

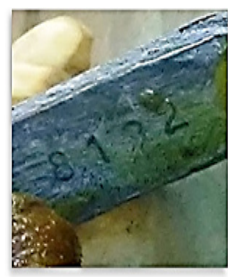

Fig. 5. Serial mark (a) pre obliteration (b) post obliteration

(c) restored by Reagent 3

\section{DISCUSSION}

Richa et al., ${ }^{4}$ performed a similar experiment on steel surface by using multiple combinations of Fry's reagent and found effective results. Reagent 3 produced the best visibility in minimum time (4-6 min) with better reproducibility among all the ten reagents used. In the study by Chisum ${ }^{15}$, a similar combination of metallic chloride (Mercuric Chloride) and a strong acid $(\mathrm{HCl})$ showed good restoration on aluminium and its alloy surfaces that is similar with the results of the present study. An alternative swabbing of $60 \%$ Hydrochloric Acid $(\mathrm{HCl})$ and $40 \% \mathrm{NaOH}$ proved to be a good etching reagent for obliterated engraved marks on aluminium and its alloys in the experiments by Baharum et al., ${ }^{10}$ Bong and Kuppuswamy ${ }^{9}$ and Peeler et al.., ${ }^{17}$. Uli et al., used an alternate swabbing of $10 \%$ Nitric Acid and $10 \% \mathrm{NaOH}$ in their study which showed good results on aluminium-silicon alloy surfaces ${ }^{2}$. Previous studies revealed that the effect of etching reagent on the metal surface is affected by the marking procedure. Engraved aluminium surfaces did not restore obliterated marks by the etching reagents used for strong metals because it corrodes most of the underlying shallow deformations $\mathbf{s}^{2,9-10}$. Stamping method potentially causes greater deformation on the metal surface that make it persistent to the exposure of strong etching reagents as observed in the present study (Reagent 3). Previous studies suggested that aluminium and its alloys show gradual corrosion to the exposure of caustic solutions like an alkali ${ }^{2}$. $\mathrm{NaOH}$ 
(Alkali) is present in most of the best-suited reagents

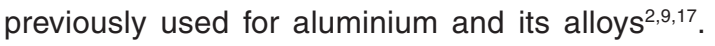
The absence of alkali probably accelerates the caustic effect on the aluminium surface that reduces the restoration time. The reagents without $\mathrm{NaOH}$ (i.e., Reagent 2, 3 and 5) restored the obliterated serial numbers faster than the reagents consisting $\mathrm{NaOH}$. A comparison between the results of the previous and the present study on aluminium surfaces is summarized in Table 3.

Table 2: The comparative representation of the consumed time by reagents including alkali and without alkali

\begin{tabular}{|c|c|c|c|c|c|}
\hline $\begin{array}{c}\text { Reagent } \\
\text { (Without Alkali) }\end{array}$ & Composition & $\begin{array}{l}\text { Consumed } \\
\text { Time (Min) }\end{array}$ & $\begin{array}{c}\text { Reagent } \\
\text { (Including Alkali) }\end{array}$ & Composition & $\begin{array}{l}\text { Consumed } \\
\text { Time (Min) }\end{array}$ \\
\hline $\begin{array}{l}\text { Reagent } 1 \\
\text { (Villella's } \\
\text { reagent) }\end{array}$ & $\begin{array}{l}\text { Glycerine } 30 \mathrm{~mL} \\
\text { Hydrofluoric acid } 20 \mathrm{~mL} \\
\text { Nitric acid }\left(\mathrm{HNO}_{3}\right) 10 \mathrm{~mL}\end{array}$ & $20-25$ & Reagent 6 & $\begin{array}{l}\text { Solution } 1 \\
10 \% \text { Sodium hydroxide } \\
\text { Solution } 2 \\
10 \% \text { Nitric acid }\end{array}$ & 60 \\
\hline $\begin{array}{c}\text { Reagent } 2 \\
\text { (Hume Rothery } \\
\text { solution) }\end{array}$ & $\begin{array}{l}\text { Copper Chloride }\left(\mathrm{CuCl}_{2}\right) 200 \mathrm{~g} \\
\text { Hydrochloric Acid }(\mathrm{HCl}) 5 \mathrm{~mL} \\
\text { Distilled water } 1000 \mathrm{~mL}\end{array}$ & 20 & Reagent 7 & $\begin{array}{l}\text { Solution } 1 \\
10 \% \text { Sodium hydroxide } \\
(\mathrm{NaOH}) \\
\text { Solution } 2 \\
25 \% \text { Nitric acid }\left(\mathrm{HNO}_{3}\right) \\
\text { (Used as highlighter for the } \\
\text { above chemical) }\end{array}$ & 58 \\
\hline $\begin{array}{l}\text { Reagent } 3 \\
\text { (Fry's }\end{array}$ & $\begin{array}{l}\text { Ferric Chloride }\left(\mathrm{FeCl}_{3}\right) 25 \mathrm{~g} \\
\mathrm{HCl} 25 \mathrm{ml}\end{array}$ & $4-6$ & Reagent 8 & $\begin{array}{l}10 \% \text { Sodium hydroxide } \\
\text { Distilled water } 90 \mathrm{~mL}\end{array}$ & 50 \\
\hline Reagent) & Distilled water $100 \mathrm{~mL}$ & & & & \\
\hline Reagent 5 & $\begin{array}{l}\text { Conc. } \mathrm{HCl} 10 \mathrm{~mL} \text { Glacial } \\
\text { acetic acid } 25 \mathrm{~mL}\end{array}$ & 30 & & & \\
\hline
\end{tabular}

Table 3: Summarized table of previous and present study on aluminium surfaces

\begin{tabular}{|c|c|c|c|}
\hline \multicolumn{4}{|c|}{ Comparative Study } \\
\hline S. No. & Study & $\begin{array}{l}\text { Composition of } \\
\text { Desirable Reagent }\end{array}$ & $\begin{array}{c}\text { Restoration Time } \\
\text { (Minutes) }\end{array}$ \\
\hline 1 & Chisum WJ, 1963 & $0.1 \mathrm{M}$ Mercuric Chloride in $0.1 \mathrm{~N}$ Hydrochloric Acid & 20 \\
\hline \multirow[t]{4}{*}{2} & Baharum et al., 2008 & Solution 1 & $03-60$ \\
\hline & & $60 \%$ hydrochloric acid & \\
\hline & & Solution 2 & \\
\hline & & $40 \%$ sodium hydroxide & \\
\hline \multirow[t]{4}{*}{3} & Uli et al., 2010 & Solution 1 & \\
\hline & & $10 \%$ Sodium hydroxide & \\
\hline & & Solution 2 & $08-40$ \\
\hline & & $10 \%$ Nitric acid & \\
\hline \multirow[t]{5}{*}{4} & Bong and Kuppuswamy, 2010 & (i) $10 \%$ Aqueous Phosphoric Acid & $2-960$ \\
\hline & & (ii) Solution 1 & \\
\hline & & $60 \%$ hydrochloric acid & \\
\hline & & Solution 2 & $02-20$ \\
\hline & & $40 \%$ sodium hydroxide & \\
\hline \multirow[t]{3}{*}{5} & Present Study & Ferric Chloride $25 \mathrm{~g}$ & \\
\hline & & Hydrochloric acid $25 \mathrm{~mL}$ & $04-06$ \\
\hline & & Distilled water $100 \mathrm{~mL}$ & \\
\hline
\end{tabular}

\section{CONCLUSION}

The present study is the first attempt to restore obliterated stamped serial numbers on the aluminium surface in contrast to all the previous studies on obliterated engraved markings. Among 10 chemical reagents used, reagent 3 (Ferric Chloride $25 \mathrm{~g}, \mathrm{HCl}$
$25 \mathrm{~mL}$ and Distilled water $100 \mathrm{~mL}$ ) produce desired results in minimum time (4-6 minute). The study also revealed that the absence of the alkaline compound potentially enhances the caustic effect to minimize the restoration time. Reagent 2, 3 and 5 including $\mathrm{HCl}$ showed a similar result as produced by reagent 6, 7 and 8 including $\mathrm{NaOH}$. But acid-containing 
reagents took lesser time to restore the obliterated numbers.

\section{ACKNOWLEDGMENT}

This research did not receive any specific grant from funding agencies in the public, commercial, or not-for-profit sectors.

\section{Conflicts of Interest}

The authors declare no conflict of interest.

\section{REFERENCES}

1. Wightman, G.; Matthew, J. Restoration of stamp marks on steel components. Forensic Science International., 2008, 180, 32-36. DOI: 10.1016/j.forsciint.2008.06.017.

2. Uli, N.; Kuppuswamy, R.; Amran, M.F.C. A survey of some metallographic etching reagents for restoration of erased engraved marks on aluminium-silicon alloy surfaces. Forensic science International., 2010, 208, 66-73. DOI: 10.1016/j.forsciint.2010.11.005.

3. Shankar, N.; Kesharwania, L.; Mishra, M.K.; Chattree, A.; Kumar, R.; Sharma, R.; Gupta. A.K. New Restoration Reagent for Development of Erased Serial Number on Copper Metal Surface. Malaysian Journal of Forensic Sciences., 2014, 5(2), 53-66.

4. Richa.; Kesharwani, L.; Gupta, A.K.; Mishra, M.K. Development of new reagent for restoration of erased serial number on metal plate. Egyptian journal of Forensic Science., 2013, 3(1), 26-34. DOI: dx.doi.org/10.1016/j. ejfs.2012.11.004.

5. Nickols, L.C. The Scientific Investigation of Crime. London: Butterworth \& Co., 1956.

6. Heard, B.J. Handbook of firearms and ballistics: Examining and interpreting forensic science evidence. $2^{\text {nd }}$ ed. Hoboken NJ: Wiley John \& Sons., 2008.

7. Zaili, M.A.M.; Kuppuswamy, R.; Harun, H. Restoration of engraved marks on steel surfaces by etching technique. Forensic science International., 2006, 171, 27-32. DOI: 10.1016/j.forsciint.2006.09.010.

8. Kuppuswamy, R.; Senthilkumar, M. Restoration of vehicle identification numbers. Journal of forensic Identification., 2004, 54, 13-21.

9. Bong,Y.U.;Kuppuswamy, R. Revealing obliterated engraved marks on high strength aluminium alloy (AA7010) surfaces by etching technique. Forensic Science International., 2010, 195, 86-92. DOI: 10.1016/j.forsciint.2009.11.018.

10. Baharum, M.I.M.; Kuppuswamy, R.; Rahman, A.A. Recovering erased engraved marks on aluminium surfaces by etching technique. Forensic Science International., 2008, 177, 221227. DOI: 10.1016/j.forsciint.2008.01.004.

11. Wahab, M.F.A.; Izwani, N.; Ghani. M.;
Kuppuswamy, R. An investigation into the suitability of some etching reagents to restoring obliterated stamped numbers on cast iron engine blocks of cars. Forensic Science International., 2012, 223, 53-63. DOI: dx.doi. org/10.1016/j.forsciint.2012.07.02012.

12. Turley, D. Restoration of Stamp Marks on Steel Components by Etching and Magnetic Techniques. Journal of Forensic Sciences., 1987, 32(3), 640-649. DOI: doi.org/10.1520/ JFS12368J13.

13. Yin, S.H.; Kuppuswamy, R. On the sensitivity of some common metallographic reagents to restoring obliterated marks on medium carbon $(0.31 \% \mathrm{C})$ steel surfaces. Forensic Science International., 2009, 183, 50-53. DOI: 10.1016/j.forsciint.2008.10.009.

14. Fortini, A.; Merlin, M.; Soffritti, C.; Garagnani, G.L. Restoration of Obliterated Numbers on $40 \mathrm{NiCrMo} 4$ Steel by Etching Method: Metallurgical and Statistical Approaches. Journal of Forensic Science., 2016, 61(1), 160 - 69. DOI: 10.1111/1556-4029.12849.

15. Chisum, W.J. A catalytic process for restoration of serial numbers on aluminium. Journal of Forensic Science Society., 1966, 6(2), 89.

16. Okayasu, M.; Sato, K.; Mizuno, M. A new etching technique for revealing the plastic deformation zone in an $\mathrm{Al}-\mathrm{Cu}-\mathrm{Mg}$ alloy. Journal of Material Science., 2008, 43, 2792-98. DOI: 10.1007/s10853-008-2544-y.

17. Peeler, G.; Gutowski, S.; Wrobel, H.; Dower, $G$. The restoration of impressed characters on aluminium alloy motorcycle frames. Journal of Forensic Identification., 2008, 58(1), 27-32.

18. Petterd, C. Encyclopedia of Forensic Science, San Diego., 2000, 1205.

19 Technical Procedure for Reagent Preparation North Carolina State Crime Laboratory, Raleigh Firearm and Tool Mark Section

20. Katterwe, H. Restoration of serial numbers. Forensic Investigation of Stolen-Recovered and Other Crime-Related Vehicles., 2006, 177-205. doi:10.1016/b978-0120884865/50041-7 